\title{
Preliminary observations on the concentration of marine bacteriophages in the water around Helgoland
}

\author{
K. Moebus \\ Biologische Anstalt Helgoland (Meeresstation); D-W-2192 Helgoland, Federal Republic \\ of Germany
}

\begin{abstract}
In a preliminary survey, conducted between August 28 and October 9, 1990, the concentration of bacteriophages in seawater sampled at intervals of 1 to 4 days near Helgoland (station Kabeltonne) was determined by using indicator bacteria which had been isolated from seawater sampled only some weeks before. With a number of bacterial strains, phage concentrations ranging between 2 and $7 \times 10^{2} \mathrm{ml}^{-1}$ were found. However, during the course of this investigation maximal concentrations lasted for a few days only. With most indicator bacteria employed, the concentration of plaque-forming units (PFU) varied in the range of $<1$ and 20-30 PFU ml ${ }^{-1}$.
\end{abstract}

\section{INTRODUCTION}

In general, the available information on marine bacteriophages is scant, but when it comes to the concentration of these viruses in their natural habitats, information is almost nil. Since Spencer's $(1955,1960)$ brief reports on the first isolations of marine phage strains, there have been hardly any attempts to determine the number of plaque-forming units (PFU) present in the source sample. This is not remarkable in view of the information presented by Spencer (1960): The seven phage strains isolated were found in about 461 of North Sea water tested either by a direct plating method (6 1, employing 600 Petri dishes) or by enrichment cultures set up with $300 \mathrm{ml}$ seawater each. With three of the seven phage strains, 1-5 PFU per $10 \mathrm{ml}$ were observed and with one about $100 \mathrm{PFU}$ per $10 \mathrm{ml}$. The remaining three strains were detected after enrichment culture only. There is only one more publication (Ahrens, 1971) dealing with (considerably higher) PFU concentrations in Kiel Bight, Baltic Sea, which is an estuarine environment.

In recent years, electron microscopic studies of seawater from various regions and habitats (Torrella \& Morita, 1979; Bergh et al., 1989; Proctor \& Fuhrman, 1990) demonstrated a high abundance of viral particles in general and bacteriophages in particular. Moreover, Proctor \& Fuhrman (1990) reported up to $7 \%$ of heterotrophic bacteria containing mature phage. These observations, highly interesting in several aspects, provide negligible information on the host organisms and none at all on the infectivity of the viruses observed. The latter factor, however, is the most important one in regard to the viruses' ecological role.

Since this author began investigations on marine bacteriophages, he has made a number of observations indicating that the chances of finding phages that will be propagated by a specific bacterial strain depend to a major extent on the time lapse 
between the isolation of the bacterium and the attempted isolation of phage from water samples collected at the same locality. In other words, the chances of detecting bacteriophages with bacteria isolated years ago are slim, while with bacteria present in the same water sample the chances are relatively high. This rule of thumb is probably also valid in regard to the distance between the geographic origins of bacteria and phages (Moebus, 1983).

From these observations it was concluded that in seawater the concentration of bacteriophages infective for any of the bacterial strains present may be greater or even far greater than expected according to the published information. Exact determination of the actual concentration of infective virions in a sample, however, depends on reliable methods and sufficiently high concentration, and even more decisively on the availability of bacteria suited to indicate the types of phage present. Generally, such bacteria will not be at hand but must be isolated from plates inoculated with the sample to be tested. Therefore, storage of the sample for 1-2 weeks, depending on the plate incubation temperature, is unavoidable. This necessity accentuates anew the main topic of recent investigations of this author, that of longevity, which is one of the central problems of marine bacteriophage ecology.

A method of overcoming problems arising from sample storage and belated availability of suitable indicator bacteria for the determination of actual PFU concentrations in seawater was tested. The results are presented in this paper.

\section{MATERIALS AND METHODS}

Me dia: The 2216E medium of Oppenheimer \& ZoBell (1952), basically composed of $5 \mathrm{~g}$ peptone, $1 \mathrm{~g}$ yeast extract, and $0.01 \mathrm{~g}$ ferric phosphate per liter of seawater mixture (i.e. $75 \%$ aged seawater), was employed as seawater bouillon (SWB) with the following additions or deviations: Seawater agar (SWA) contained $1.5 \%$ agar, soft seawater agar (sSWA) was prepared with $0.6 \%$ agar, and in nutrient-reduced seawater bouillon (SWB/ 5 ) the concentration of peptone and yeast extract was only one fifth of that in SWB.

Methods: Seawater was sampled from about $1 \mathrm{~m}$ depth at the station 'Kabeltonne' between the island of Helgoland and the adjacent Düne island. Platings were performed within about one hour after sampling, and all incubations were at $20^{\circ} \mathrm{C}$. Seawater was stored at $5^{\circ} \mathrm{C}$ in the dark, generally for 8 to 9 days before the first test for present phage could be performed with bacteria derived from the same sample.

PFU concentrations were determined by means of the double-layer method (Adams, 1959), employing bottom layers of $10 \mathrm{ml}$ SWA. Seawater was used undiluted, with portions of between 0.1 and $1.0 \mathrm{ml}$ placed on the bottom layer and mixed with $2.5 \mathrm{ml}$ of sSWA seeded with about $10^{8} \mathrm{ml}^{-1}$ bacteria of the respective indicator strain. Sets of 2 to 3 plates per sample size and indicator strain were used. Bacteria used in PFU titrations were cultivated in SWB/5 or SWB at $1 \mathrm{rpm}$, inoculated from stocks grown on SWA slants.

All but one ( $\mathrm{H} 71$, isolated in 1988) of the indicator (host) strains employed throughout were isolated, tested for phage sensitivity, and purified during the course of a separate investigation performed somewhat earlier in 1990. An additional set of some 30 strains was used only once at the end of this investigation. Only strains forming colonies of $=>2$ $\mathrm{mm}$ in diameter (after 7 days at $20^{\circ} \mathrm{C}$ ) were chosen. 
Generally, the indicator strains were isolated from plates inoculated with freshly collected raw seawater (rsw). However, 12 strains, designated A, B, C in combination with numbers, were derived from plates inoculated with unsupplemented rsw incubated for 1 (A) to 3 (C) days at $20^{\circ} \mathrm{C}$. Phage sensitivity of bacteria was established by the use of cell-free preparations produced in various ways from the same rsw sample from which the bacteria had been derived (a detailed description of the method will be presented elsewhere). For purification, bacteria were consecutively streaked on SWA.

\section{RESULTS}

During the investigations of seawater samples collected from the middle of March to the beginning of August 1990, hundreds of bacterial strains were isolated and tested for their ability to propagate phages present in the respective samples. In a sample taken on March 19 no phage at all could be detected, but in each sample collected later in the year phages were found with a number of bacterial isolates. Generally, samples were tested for phage with indicator bacteria derived from the preceeding sample(s) as well as from the last one, the latter being normally available after 8 days of storage of the sample. The only exception relates to the sample collected on August 6 , the investigation of which was interrupted for almost 3 weeks. When the present investigation was started on August 28 , some 20 indicator strains were available.

Among the bacterial isolates picked from plates inoculated with freshly collected seawater, truly identical strains (doublets) in regard to phage sensitivity patterns were rarely found, judging from the results of spot tests (mostly of single-plaque eluates) and titrations performed with various materials. This observation was unexpected since unintentional selection was avoided in the strictest possibly way by isolating all colonies of $=>2 \mathrm{~mm}$ in diameter which could be picked from a plate without contamination. There were, however, a number of more or less closely related bacterial strains which differed in sensitivity to the same phage strain(s). While true bacterial doublets were excluded from this study, some closely related strains have been included (see below).

Representative results of this investigation are presented in Table 1 which displays the numbers of plaque-forming units (PFU) observed with the various host bacteria in samples of $1 \mathrm{ml}$ of seawater. Since the PFU concentration in most cases was very low, the findings obtained with sets of 2 to 3 plates poured in parallel are presented as follows: Up to $20 \mathrm{PFU}$ per set of plates are presented, for example, as 8 or 9.5 when 16 or 19 plaques, respectively, were counted on 2 plates. With more than $20 \mathrm{PFU}$ per set, rounded numbers are given. (The same rule relates to the data presented in Tables 2 and 3.)

As can be seen from Table 2, in the sample taken on August 6 more than 100 PFU $\mathrm{ml}^{-1}$ were observed with 6 out of 17 proven host strains. Due to a forced interruption of the running investigations, changes in the composition of the phage population observed on August 6 could not be followed for 3 weeks. When the work was resumed, the concentration of phages most numerous on August 6 was reduced by, at least, one power of ten. As demonstrated in Figure 1, depicting some exemplary findings, the concentration of phages detectable with most of the host strains used at that time continued to decrease until September 11. From September 13 on, a short period of phage reproduction was observed with 10 out of 18 host bacteria. After one week, this phage reproduction reached its peak and, in some cases, led to maximal PFU numbers equalling those 


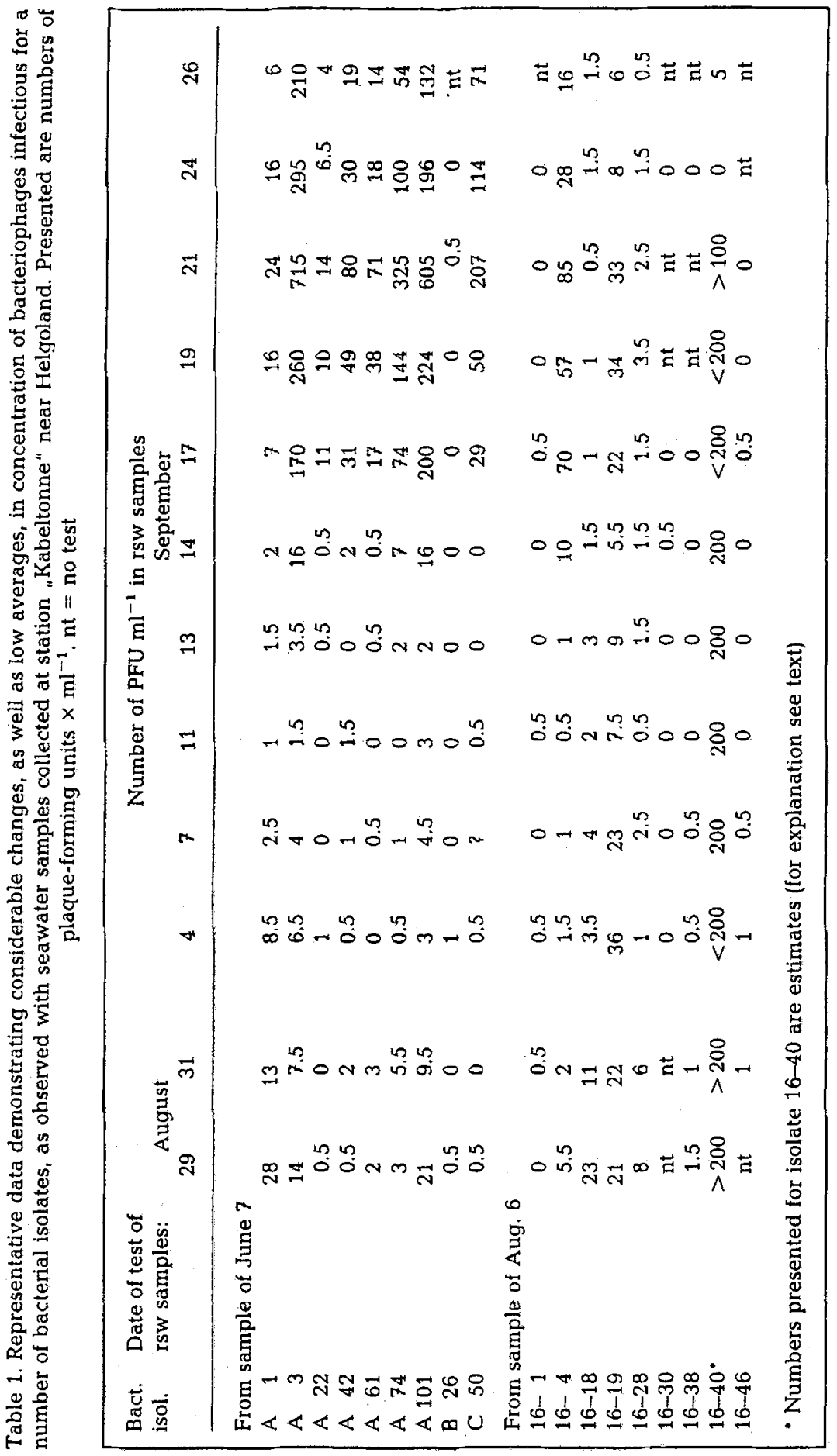




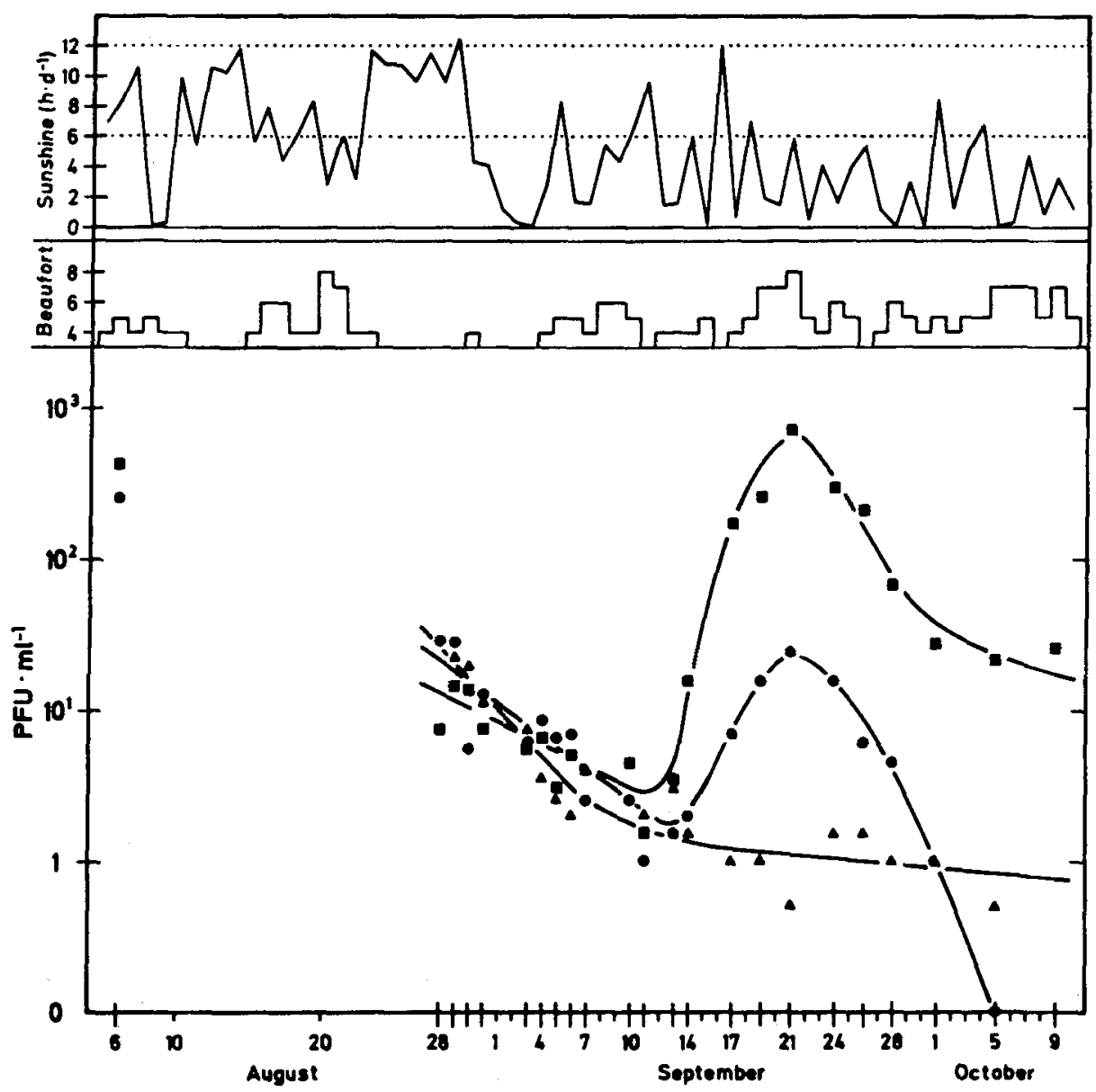

Fig. 1. Changes in bacteriophage concentrations of seawater samples collected at station "Kabeltonne" near Helgoland, as observed with bacterial isolates A3 (๑), A101 (๑), and 16-18 (A), and changes in meteorological parameters

observed on August 6. Within another week, however, phage concentrations again were reduced by about one power of ten.

Of the indicator bacteria employed throughout, the following strains are related: $A 3$ and $\mathrm{A} 22$ on the one hand, A42, A61, A74 and C50 on the other. In spot tests performed with numerous eluates of plaques directly derived from freshly collected seawater, it was invariably found that plaques grown with host A22 resulted in eluates of about equal activity on $\mathrm{A} 3$ and $\mathrm{A} 22$, whereas plaques grown on host $\mathrm{A} 3$ produced eluates of grossly reduced activity on $A 22$, compared with that on $A 3$. With the other 4 host bacteria, less pronounced differences were observed, although with plaques grown on A74 eluates were sometimes obtained that lacked any activity on A42 or on A42 and A61. Differences between the members of both groups of related strains are also clearly discernible from the data presented in Table 1. 
During the course of this investigation, it was observed that with a number of host strains more than one type of phage plaque developed, but in many of these cases the diversity of phage obviously was feigned by the high variability of the plaques. Generally, such "variable" plaques were characterized by a varying number of concentric zones of different turbidity around a less turbid centre. Following consecutive isolations of such "variable" plaques, eluates either again and again gave rise to mixed plaque populations or to plaques the centre of which became larger (and clearer) with each isolation. The latter plaque type probably always occurred in "variable" plaque populations.

In general, there was little change in the plaque types observed during the whole period of observation. With a few host strains, a new plaque type was found once in a while. This usually remained a singular event. With most of the host strains referred to in the last paragraph, however, plaques not seen before were found for the first time on September 17 , i.e. when the phage concentration began to increase, and until the end of this investigation. These plaques resembled very much those large and clear ones, which occurred in increasing proportion during consecutive isolations of certain "variable" plaques mentioned above.

The strangest type of plaque ever seen by this author is shown in Figure 2. The majority of plaques occurred as clusters of small units, the latter also being present singly. Upon eluation, both types gave rise to clusters as well as to single units. These plaques were observed with almost all rsw samples tested. Although PFU numbers could be estimated only, there is no doubt that changes in the concentration of these plaque formers were not in phase with that of the other PFU observed. Since the particles causing these unusual plaques could be passed without loss through filters of $0.15 \mu \mathrm{m}$
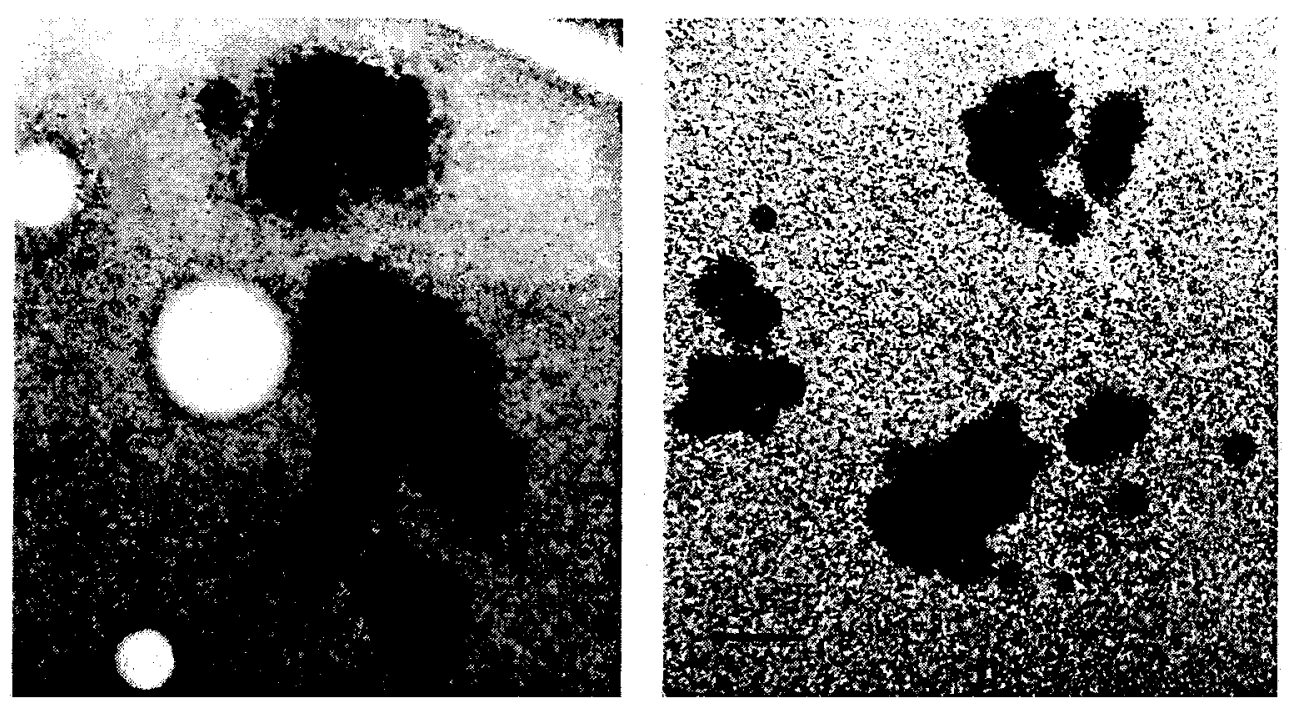

Fig. 2. Composite plaques observed with isolate 16-40. Left: plaques after plating of $1 \mathrm{ml}$ of freshly. collected raw seawater, their contours blurred due to thickness as well as wetness of the soft agar overlay. Right: plaques as developed under standard plating conditions from a cell-free stock of the lytic principle. Bar represents $1 \mathrm{~mm}$ 
pore size, it can be excluded that the plaques were produced by bacteria or even larger organisms. Whether the plaques in fact were produced by phage remains an open question. Unfortunately, attempts to produce high titer stocks with this agent were unsuccessful, and the activity of the stocks prepared decreased very rapidly.

Investigations performed with rsw during storage at $5^{\circ} \mathrm{C}$ in the dark generally demonstrated rapid decrease in phage concentration under these conditions. The results found with rsw collected on August 6 are shown in Table 2.

Table 3 presents data concerning the influence of storage on the sample collected on September 26, as well as remarkable differences in the concentration of distinct types of phage as revealed by indicator bacteria, derived from rsw collected June 7, August 6 , and September 26, respectively. In the sample taken on September 26, more than 100 PFU $\mathrm{ml}^{-1}$ were found, after 13 days of storage with two host bacteria isolated more than 3 months before, whereas the highest count with bacteria isolated from the investigated sample was only $54 \mathrm{PFU} \mathrm{ml}{ }^{-1}$. (Note, that in the case of two bacterial strains an increase of PFU numbers during storage was observed.)

Plaques found in platings of freshly collected rsw were isolated several times and all the eluates were spot-tested on lawns of all the host strains with which plaques were found from the respective rsw sample. With already known plaque types, these cross reaction tests rarely revealed slightly differing patterns of host range of the phages, or of sensitivity of host bacteria to phage, which could probably be attributed to the relative inaccuracy of the spot-test method. Even newly detected plaque types generally fit into the already known patterns. The host range of the phage strains tested was always small, and in most cases restricted to the host strain with which the plaques were found (= original host).

To demonstrate this in some detail, the results of a test performed with the rsw sample taken on September 26 after storage at $5^{\circ} \mathrm{C}$ for 13 days are presented. On October 9 it was tested for phage with 47 host bacteria, 34 of which were newly derived from the very same rsw sample. Plaques were found with 26 of the new host strains and with 12 out of the 13 (old) bacterial strains employed in preceeding tests. With eluates of 55 plaques, found with the 38 host strains, the following results were obtained:

(1) Two of the new host strains were doublets with narrow phage-sensitivity patterns and are, together with 3 eluates, excluded from the following evaluation.

(2) Phage activity only on the original host was found in $17(57 \%)$ eluates on new, and in $6(27 \%)$ eluates on old bacterial strains.

(3) Phage activity on the original host and on one additional host was observed in $5(17 \%)$ eluates on new host strains, and in $6(27 \%)$ eluates on old host strains. Of the 5 phage strains found with new hosts, only one also infected an old host, while among the 6 phages found with old hosts 3 were also active on a new host.

(4) With 8 plaques, each one developed on a different host, and 10 plaques found with 4 old hosts, infection of up to 12 and 4 bacterial strains, respectively, was observed. The old hosts (A42, A61, A74, and C50), already described above as being closely related, have been included in this test mainly to confirm former results. Regarding the 8 phage strains found with new hosts, their plaques being very similar in appearance with small diameters ranging between 0.3 and $0.5 \mathrm{~mm}$, at least 4 , possibly 5 different host-range patterns were observed. Moreover, with 4 of the 8 hosts which differed in their sensitivity patterns to phage from the small plaques, 4 different phage strains were found, each 
Table 2. Observations made with seawater collected on August 6 and stored at $5^{\circ} \mathrm{C}$ in the dark. Presented are numbers of plaque-forming units $\times \mathrm{ml}^{-1}$. With several indicator strains the plaques on plates of the test performed on August 6 were too crowded to be counted. In these cases estimates are presented. int $=$ no test

\begin{tabular}{|lrrrr|}
\hline $\begin{array}{l}\text { Bacterial } \\
\text { isolate }\end{array}$ & Date of test: & Aug. 6 & Number of PFU ml & Aug. 7 \\
Aug. 28 & Sept. 26 \\
\hline A 1 & $>250$ & 260 & 20 & 6 \\
A 3 & $>200$ & 430 & 30 & 19 \\
A 22 & 26 & nt & 0 & 1 \\
A 42 & $>100$ & 105 & 5 & 2.5 \\
A 61 & 90 & nt & 5 & 3.5 \\
A 74 & 350 & 370 & 35 & 20 \\
A 101 & 300 & 540 & 30 & nt \\
B 26 & 35 & nt & 0.5 & nt \\
C 50 & 60 & nt & 1.5 & \\
\hline
\end{tabular}

Table 3. Data obtained with seawater sampled on September 26 and tested before and after storage at $5^{\circ} \mathrm{C}$ in the dark for 13 days. Presented are numbers of plaque-forming units $\times \mathrm{ml}^{-1}$. Note that bacteria isolated from this sample indicated lower bacteriophage titers than isolates derived 3 months before, and that with bacterial strains C 50 and 16-40, derived from samples collected on June 7 and August 6, respectively, increases in PFU titer during storage were observed

\begin{tabular}{|c|c|c|c|c|c|}
\hline \multirow{2}{*}{$\begin{array}{l}\text { Bact. } \\
\text { isol. }\end{array}$} & \multicolumn{2}{|c|}{ PFU ml ${ }^{-1}$} & \multirow{2}{*}{$\begin{array}{l}\text { Bact. } \\
\text { isol. }\end{array}$} & \multicolumn{2}{|c|}{$\mathrm{PFU} \mathrm{ml} \mathrm{ml}^{-1}$} \\
\hline & Sept. 26 & Oct. 9 & & Sept. 26 & Oct. 9 \\
\hline \multicolumn{3}{|c|}{ From rsw of June 7} & \multicolumn{3}{|c|}{ From rsw of Sept. 26} \\
\hline A 1 & 6 & nt & VI- 3 & & 34 \\
\hline A 3 & 210 & 125 & VI- 11 & & 2 \\
\hline A 22 & 4 & 2.5 & VI- 30 & & 23 \\
\hline A 42 & 19 & 12 & VI- 45 & & 18 \\
\hline A 61 & 14 & 8 & VI- 51 & & 7.5 \\
\hline A 74 & 54 & 40 & VI- 54 & & 11 \\
\hline A 101 & 132 & 118 & $V I-60$ & & 54 \\
\hline \multirow[t]{2}{*}{ C 50} & 71 & 163 & VI- 98 & & 4 \\
\hline & & & VI-109 & & 2.5 \\
\hline \multicolumn{3}{|c|}{ From rsw of August 6} & VI-128 & & 2.5 \\
\hline $16-4$ & 16 & 14 & VI-134 & & 25 \\
\hline $16-18$ & 1.5 & 1 & VI-144 & & 2 \\
\hline $16-19$ & 6 & 1.5 & VI-145 & & 39 \\
\hline $18-28$ & 0.5 & 0 & VI-156 & & 1.5 \\
\hline $16-40$ & 4.5 & 71 & VI-170 & & 1 \\
\hline
\end{tabular}

forming larger and almost clear plaques and infecting one host only. Since the latter phages did not infect the other 4 new host strains, the 8 bacterial isolates in question represented in effect at least 5 phage-sensitivity patterns.

Finally, the results of phage-sensitivity tests performed with some 700 bacterial isolates derived from 6 rsw samples employed in this investigation are presented in Table 4 . 
All bacteria were tested with high titer stocks of phage H7/2 (isolated in 1976) and of 18 to 24 phage strains isolated in May and June 1990. Only the bacterial isolates derived from rsw sample No. 18 (designated as VI-xy in Table 3) were also tested with cell-free preparations produced from this rsw sample. As can be seen from Table 4, the portion of

Table 4. Results of screenings for the number of phage-sensitive bacteria present in populations encountered during a time of conspicuous changes in the concentration of bacteriophages observed in seawater samples collected at station "Kabeltonne" near Helgoland

\begin{tabular}{|c|c|c|c|c|c|c|c|}
\hline \multicolumn{2}{|c|}{ Isw Sample } & \multicolumn{2}{|c|}{ CFU ml $\mathrm{ml}^{-1}$} & \multicolumn{4}{|c|}{ Numbers of bacterial isolates tested } \\
\hline \multirow[t]{2}{*}{ No. } & \multirow[t]{2}{*}{ Date } & \multirow[t]{2}{*}{ Sum } & \multirow[t]{2}{*}{$\mathrm{ICFU}^{*}$} & \multirow[t]{2}{*}{ Total } & \multicolumn{3}{|c|}{ Sensitive to } \\
\hline & & & & & $\mathrm{H} 7 / 2$ & $\cdots$ & 千車 \\
\hline 05 & 03. Sept. & $4.5 \times 10^{3}$ & $8.8 \times 10^{2}$ & 113 & 3 & $0 * *$ & \\
\hline 08 & 06. Sept. & $4.3 \times 10^{3}$ & $1.9 \times 10^{3}$ & 118 & 1 & $2 * *$ & \\
\hline 10 & 10. Sept. & $2.9 \times 10^{3}$ & $6.5 \times 10^{2}$ & 88 & 3 & $2 * *$ & \\
\hline 12 & 13. Sept. & $2.9 \times 10^{3}$ & $4.7 \times 10^{2}$ & 115 & 9 & $7 * * *$ & \\
\hline 14 & 17. Sept. & $2.6 \times 10^{3}$ & $5.8 \times 10^{2}$ & 99 & 8 & $2 * \cdots$ & \\
\hline 18 & 26. Sept. & $8.2 \times 10^{3}$ & $2.6 \times 10^{3}$ & 203 & $34 \mathrm{~T}+\mathrm{T}$ & $1-4 \mp$ & 34干玨 \\
\hline \multicolumn{8}{|c|}{$\begin{array}{l}\text { * } 1 \mathrm{CFU}=\text { formers of large colonies (diam. } \geq 2 \mathrm{~mm} \text { in } 7 \mathrm{~d} \text { at } 20^{\circ} \mathrm{C} \text { ) } \\
\text { phages derived from rsw collected on June } 7 \text { and August } 6,1990 \\
18 \text { phage strains in test } \\
24 \text { phage strains in test, } 3 \text { doubtful observations } \\
\text { 1 phages present in cell-free preparations } \\
\text { preparations; altogether, phage sensitivity was observed in } 53 \text { of the } 203 \text { bacterial isolates } \\
\text { tested }\end{array}$} \\
\hline
\end{tabular}

bacterial isolates sensitive to phages isolated only 2 to 3 months before was always low, whereas the portion of isolates sensitive to cell-free preparations was within the range of the 10 to $15 \%$ observed in preceeding experiments.

\section{DISCUSSION}

Soon after the detection of bacteriophages by Twort (1915) and d'Herelle (1917), the latter coining the term bacteriophage, these viruses were also observed in samples of seawater taken nearshore but they were found to represent types introduced by rivers or sewage outfalls. For quite a number of years, bacteriophages were studied as one of the several factors influencing the survival of terrestrial bacteria (Raettig, 1958; ZoBell, 1946), while the search for truly marine phages remained futile. As noted by ZoBell (1946, p. 83), bacteriophages have for many years not been detected from seawater "collected beyond the littoral zone" and that "it is very doubtful if the sparse bacterial population characteristic of the open ocean is conducive to the development or activity of bacteriophage". When Spencer (1955) reported the first isolation of a marine bacteriophage strain from the North Sea, his paper seemingly went as unnoticed as Twort's (1915), and Spencer himself gave up marine bacteriophage research after publishing a few more reports (Spencer, 1957, 1960, 1963). Since then, our information on marine bacteriophage ecology has been increased by a number of occasional publications and, especially, by 
the systematic research of Hidaka and coworkers during the seventies (for references see Moebus, 1987). However, regarding the concentration of bacteriophages encountered in marine environments, our knowledge is almost as meagre as that of 35 years ago.

Considering this void, the paper by Bergh et al. (1989), reporting concentrations of viral particles in marine environments of up to $10^{7} \mathrm{ml}^{-1}$, understandably stirred considerable attention, as indicated by the headline of an article by Sherr (1989): "And now, small is plentiful." Unfortunately, these highly interesting electron microscopic observations, confirmed by Proctor \& Fuhrman (1990), cannot tell us much about the nature of the viral particles seen and nothing about their infectivity. Knowledge of the latter factor is essential to our understanding and appreciating the findings reported by Bergh et al. (1989) and Proctor \& Fuhrman (1990). Furthermore, there is no published information on parameters such as adsorption rate, latent period, and burst size as observed with marine phages under (almost) natural conditions. Such knowledge, however, is a basic requirement for meaningful calculations regarding the in situ development of phage-host systems (PHS). The calculations presented by Bergh et al. (1989) are based on findings obtained with optimalized laboratory cultures of non-marine PHS and, therefore, must be regarded with caution. Moreover, observations made by this author during studies performed under low nutrient conditions contradict these calculations but are in general agreement with the concept of "minimum bacterial density for bacteriophage replication" of Wiggins \& Alexander (1985).

The results presented in this paper are in agreement with the often cited statement that marine bacteriophages generally occur at low concentration. However, they also demonstrate that with proper methods higher numbers of marine phages will be found than reported before, and that isolation of marine phages must not meet with difficulties, even if enrichment cultures are not employed.

With regard to the latter statement, however, restrictions have to be made. First of all, it very probably holds true only for environments supporting relatively high concentrations of bacteria, such as the North Sea. Secondly, according to this author's experience, it is difficult to demonstrate the presence of phage propagated by slow growing bacteria, and even more difficult to investigate thoroughly such phage-host systems. In nature they may be important.

In regard to an assessment of bacteriophages as factor in marine microbial life, not only the concentration of infective particles is of major importance, but also their longevity. This author, who in recent years has paid much attention to the latter problem, obtained (unpublished) data which suggested that phage particles in nature will probably survive for months. The present investigation, however, indicates that phages either lose their infectivity rather rapidly or that they are removed from the water column.

As can be seen in Figure 1, following the stormy days of August 20 and 21, calm weather prevailed for two weeks, with little sun (and some rain) during the second. During this period, decreasing concentrations of phages were found, the decrease obviously continuing from unknown maxima. On September 21 , the concentrations of phages detectable with 10 out of 18 host strains synchronously attained a new maximum, just when the stormy weather lasting for 3 days reached its peak. Immediately afterwards, the concentration of phages started to decrease, and decreased so rapidly that it seems plausible to ascribe, at least in part, the loss of PFU to the attachment of virions to settling sediment particles stirred up during the storm. If this explanation is correct, it 
may also relate to the decrease in phage concentration observed prior to the initial phase of this investigation which started 10 days after a couple of stormy days. (Attachment to sediment particles in marine environments was observed by numerous investigators interested in the survival of enteric viruses and non-marine phages. Regarding marine phages, no information is available.)

If, however, adsorption to sediment particles was not involved in the observed reduction of $\mathrm{PFU}$, it must be assumed that the loss of infectious phage was due to factors such as sunlight or the activity of organisms. In any case, one would have to assume that under natural conditions marine bacteriophage cannot maintain their infectivity for weeks or even months. In this case, not only would there be still no answer at hand to the question as to how marine phage-host systems are maintained in nature, but, in view of the findings reported by Bergh et al. (1989) and Proctor \& Fuhrman (1990), a new question would attain prominence: for how long after losing infectivity do phage particles look like undamaged phage particles in the electron microscope?

Concerning the influence of storage of rsw on phage infectivity, only few data could be collected. They indicate that even at $5^{\circ} \mathrm{C}$ in the dark, phages may rapidly lose their infectivity. Not too much attention should be paid to differences between the PFU numbers presented in Table 2 under August 6 and 7. In plates poured with several host bacteria on August 6, plaques were too crowded to be counted accurately, this difficulty being enhanced by use of $1 \mathrm{ml}$ rsw per plate in the first test of the sample. Although the reproduction of phages during one day of storage cannot be excluded with certainty, it is assumed not to have taken place.

Among the most interesting findings of this investigation is the observation of a predominantly narrow host range with the phages and, correspondingly, of bacterial strains mostly sensitive to one or few phage strain(s) only. It helps us to understand why isolating phage infective for bacteria that have been derived several years ago generally meets with difficulties. On the other hand, it poses the following questions:

- why even quite large numbers of PFU were found with bacteria derived from samples collected several weeks before September 26, but not with bacteria isolated from sample No. 18 taken on September 26, as demonstrated in Table 3.

- why phages in each rsw sample tested with bacteria derived from the same sample were detected with only a small fraction (about 10-15\%) of the many bacteria isolated. (It must be pointed out here that quite a number of bacterial strains, shown to be susceptible to phage by means of cell-free preparations, failed to detect phage from the respective rsw sample by direct platings. Certainly, this was due in most cases to low phage concentration.)

In view of the fact that in the second half of September a pronounced increase in PFU numbers was observed with several host bacteria, one would expect that the number of bacteria sensitive to the phages in question increased in advance of phage propagation. As shown in Table 4, this was seemingly not the case. Instead of bacteria the sensitivity of which corresponded with that of isolates A3, A74 or A101, i.e. of strains signalizing the strongest increases in PFU concentration (Table 1), the phage-sensitive isolates found in samples taken between September 3 and 13 were related only to bacteria with which minor increases in PFU concentration were detected.

At the present, there are no clear solutions to the problems outlined in both the last paragraphs. However, there are still vague observations indicating the possibility that 
infection of marine bacteria by phage may not under all circumstances result in immediate phage reproduction (or in lysogenization). If these observations can be confirmed, answers to some of the questions posed here will be at hand.

Acknowledgements. The author expresses his gratefulness to Miss Sandra Hierse, whose reliable help and everlasting pleasantness are sorely missed. He also extends his thanks to the staff of the Weather Station Helgoland for generously providing data.

\section{LITERATURE CITED}

Adams, M. H., 1959. Bacteriophages. Interscience Publ., New York, 592 pp.

Ahrens, R., 1971. Untersuchungen zur Verbreitung von Phagen der Gattung Agrobacterium in der Ostsee. - Kieler Meeresforsch. 27, 102-112.

Bergh, O., Borsheim, K. Y., Bratbak, G. \& Heldal, M., 1989. High abundance of viruses found in aquatic environments. - Nature, Lond. 340, 467-468.

Herelle, F. de, 1917. Sur un microbe invisible antagoniste des bacilles dysentériques. - C. r. hebd. Séanc. Acad. Sci. 165, 373-375.

Moebus, K., 1983. Lytic and inhibition responses to bacteriophages among marine bacteria, with special reference to the origin of phage-host systems. - Helgoländer Meeresunters. 36, 375-391.

Moebus, K., 1987. Ecology of marine bacteriophages. In: Phage ecology. Ed. by S. M. Goyal, C. P. Gerba \& G. Bitton. Wiley, New York, 137-156.

Oppenheimer, C. H. \& ZoBell, C. E., 1952. The growth and viability of sixty-three species of marine bacteria as influenced by hydrostatic pressure. $-\mathrm{J}$. mar. Res. 11, 10-18.

Proctor, L. M. \& Fuhrman, J. A., 1990. Viral mortality of marine bacteria and cyanobacteria. - Nature, Lond. $343,60-62$.

Raettig, H., 1958. Bakteriophagie 1917-1956. Fischer, Stuttgart, 2, 1-344.

Sherr, E. B., 1989. And now, small is plentiful. - Nature, Lond. 340, 429.

Spencer, R., 1955. A marine bacteriophage. - Nature, Lond. $175,690$.

Spencer, R., 1957. A possible example of geographical variation in bacteriophage sensitivity. $-\mathrm{J}$. gen. Microbiol. 17, XI.

Spencer, R., 1960. Indigenous marine bacteriophages. - J. Bact. 79, 614.

Spencer, R., 1963. Bacterial viruses in the sea. In: Symposium on marine microbiology. Ed. by C. H. Oppenheimer. Thomas, Springfield, Ill., 350-365.

Torrella, F. \& Morita, R. Y., 1979. Evidence by electron micrographs for a high incidence of bacteriophage particles in the waters of Yaquina Bay, Oregon: ecological and taxonomical implications. - Appl. environ. Microbiol. 37, 774-778.

Twort, F. W.; 1915. An investigation of the nature of ultra-microscopic viruses. - Lancet 2, 1241-1243.

Wiggins, B. A. \& Alexander, M., 1985. Minimum bacterial density for bacteriophage replication: Implications for significance of bacteriophages in natural ecosystems. - Appl. environ. Microbiol. 49, 19-23.

ZoBell, C. E., 1946. Marine microbiology. Chronica Botanica Co., Waltham, Mass., 240 pp. 